IZA DP No. 5024

School Competition and Students' Entrepreneurial Intentions: International Evidence Using Historical Catholic Roots of Private Schooling

Oliver Falck

Ludger Woessmann

June 2010 


\title{
School Competition and Students' Entrepreneurial Intentions: International Evidence Using Historical Catholic Roots of Private Schooling
}

\author{
Oliver Falck \\ Ifo Institute, CESifo \\ and Max Planck Institute of Economics \\ Ludger Woessmann \\ University of Munich, Ifo Institute, \\ CESifo and IZA \\ Discussion Paper No. 5024 \\ June 2010 \\ IZA \\ P.O. Box 7240 \\ 53072 Bonn \\ Germany \\ Phone: +49-228-3894-0 \\ Fax: +49-228-3894-180 \\ E-mail: iza@iza.org
}

Any opinions expressed here are those of the author(s) and not those of IZA. Research published in this series may include views on policy, but the institute itself takes no institutional policy positions.

The Institute for the Study of Labor (IZA) in Bonn is a local and virtual international research center and a place of communication between science, politics and business. IZA is an independent nonprofit organization supported by Deutsche Post Foundation. The center is associated with the University of Bonn and offers a stimulating research environment through its international network, workshops and conferences, data service, project support, research visits and doctoral program. IZA engages in (i) original and internationally competitive research in all fields of labor economics, (ii) development of policy concepts, and (iii) dissemination of research results and concepts to the interested public.

IZA Discussion Papers often represent preliminary work and are circulated to encourage discussion. Citation of such a paper should account for its provisional character. A revised version may be available directly from the author. 


\section{ABSTRACT \\ School Competition and Students' Entrepreneurial Intentions: International Evidence Using Historical Catholic Roots of Private Schooling*}

School choice research mostly focuses on academic outcomes. Policymakers increasingly view entrepreneurial traits as a non-cognitive outcome important for economic growth. We use international PISA-2006 student-level data to estimate the effect of private-school competition on students' entrepreneurial intentions. We exploit Catholic-Church resistance to state schooling in $19^{\text {th }}$ century as a natural experiment to obtain exogenous variation in current private-school shares. Our instrumental-variable results suggest that a 10 percentage-point higher private-school share raises students' entrepreneurial intentions by 0.3-0.5 percentage points (11-18 percent of the international mean) even after controlling for current Catholic shares, students' academic skills, and parents' entrepreneurial occupation.

JEL Classification: I20, L33, L26, Z12

Keywords: $\quad$ private school competition, entrepreneurship, Catholic schools

Corresponding author:

Ludger Woessmann

Ifo Institute for Economic Research

at the University of Munich

Poschingerstraße 5

81679 München

E-mail: woessmann@ifo.de

\footnotetext{
* Comments from Eric Hanushek, Dietmar Harhoff, Elke Luedemann, Paul Peterson, and seminar participants at Stanford University are gratefully acknowledged. Falck is indebted to the Program on Education Policy and Governance (PEPG), Kennedy School of Governance, Harvard University, and in particular to Paul Peterson and Edward Glaeser, for their hospitality during the research visit that allowed work on this research, and to the Fritz Thyssen Foundation for partial funding of the research visit. Woessmann gratefully acknowledges the support and hospitality provided by the W. Glenn Campbell and Rita Ricardo-Campbell National Fellowship of the Hoover Institution, Stanford University.
} 


\section{Introduction}

Research on the effects of competition in the school system has mostly focused on the cognitive skills of students, as measured by standardized tests in subjects such as mathematics, reading, and science. While cognitive skills are important for individual and national economic outcomes (Hanushek and Woessmann 2008), other skills beyond the cognitive kind are generally viewed as additional important outcomes of schooling. In particular, recent thinking on the determinants of economic growth stresses the importance of innovation and creative destruction in a Schumpeterian spirit (e.g., Aghion and Howitt 2009; Audretsch 2007; Baumol 2002; Murphy, Shleifer, and Vishny 1991), which places the focus on entrepreneurship. ${ }^{1}$ In line with this, policymakers around the world are increasingly wondering whether entrepreneurial traits can be nurtured in the education system (see Oosterbeek, van Praag, and Ijsselstein 2010 for references). There is clearly substantial variation across countries: Our data suggest that the share of 15-year-old students expressing entrepreneurial intentions varies from less than 1 percent in Denmark, Japan, Germany, and Portugal to more than 7 percent in the Czech Republic and the Netherlands, and other work has shown that students' intentions are strongly linked to later actually becoming an entrepreneur. Why do countries differ so strongly in the entrepreneurial spirits of their students? Is it solely innate traits and family environments, or are entrepreneurial spirits amenable to school policy? Recent evidence suggests that explicit entrepreneurship education programs seem to have failed in raising entrepreneurial intentions (Oosterbeek, van Praag, and Ijsselstein 2010).

To study whether school systems can affect entrepreneurial traits, in this paper, we estimate the effect of competition from privately operated schools on the entrepreneurial intentions of students. By affecting how schools are run, private-school competition might be an institutional feature of the school system that creates a general school climate supportive of entrepreneurial spirit. Our use of international variation exploits long-standing differences in school competition, allowing us to identify long-term general-equilibrium effects of competition, which are the focus of most economic arguments for school competition but usually escape studies evaluating smallscale programs. To avoid problems from students not being randomly assigned to schools within

\footnotetext{
1 See van Praag and Versloot (2007) for an encompassing review of the empirical literature showing that entrepreneurship has important effects on employment creation, innovation, and productivity growth and creates spillovers beyond the own firm.
} 
a system but sorting themselves into public and private schools in ways that may be correlated with their entrepreneurial disposition, we measure private competition as the aggregate share of privately operated schools in a country (while using outcomes and control variables at the individual student level in microeconometric regressions).

The simple cross-country association between private-school shares and students' entrepreneurial intentions may, however, still be subject to different forms of endogeneity bias. Most importantly, there may be a higher tendency to set up private schools in more entrepreneurial regions. More generally, other omitted factors related to the demand or supply side of the school system may also be correlated with both private schooling and students' entrepreneurial intentions. To address such endogeneity issues, we exploit the fact that resistance of the Catholic Church to state schooling in the $19^{\text {th }}$ century has repercussions for the size of the private school sector to these days. Following West and Woessmann (2010), we use this historical source of variation as a natural experiment to identify exogenous variation in private school competition. Our instrumental-variable specification uses the share of Catholics in 1900 interacted with an indicator for Catholicism not being the state religion, as Catholics had no need to opt out of the state school system if the Church could control it - as an instrument for current private-school shares. Because identification in this setting comes from long-term variation in school competition and current students' parents may already have been exposed to the system and transmitted entrepreneurial intentions to their children, our estimations control for whether the students' parents, as well as the parents of the students' peers, have entrepreneurial occupations. In addition, we can control for individual students' cognitive skills in mathematics and science. Given the historical nature of our instrument, we go further to control for the current share of Catholics in a country. In fact, the current share of Catholics is negatively associated with students' entrepreneurial intentions in our second-stage equation, suggesting that our results are not driven by a direct effect of religion on entrepreneurship.

Our cross-country student-level analyses suggest that private-school competition has a positive causal effect on the entrepreneurial intentions of students. Larger historical Catholic shares that translate into a 10 percentage point larger private school sector today increase the share of students with entrepreneurial intentions by 0.3-0.5 percentage points. This is a quantitatively substantial effect, viewed against the international mean of 2.8 percent of students indicating entrepreneurial intentions. Additional analyses suggest that this is mostly an effect of 
increased competition in the system, rather than of a mere advantage of private operation, as public-school students in countries with larger private-sector competition profit as much as their private-school compatriots. The results show that school competition may indeed have effects beyond traditional measures of academic achievement, on relevant non-academic outcomes.

Several mechanisms may lie behind this effect. Traditional economic arguments stress that competition from privately operated schools has positive general-equilibrium effects on the outcomes of the system because it creates incentives to enact quality-enhancing innovations and to contain cost within the public sector (Friedman 1962). This may lead to better outcomes not only in the academic sphere, but also in terms of non-academic measures such as entrepreneurial traits. Critics of this view argue, though, that greater private schooling may lead to more segregation rather than better outcomes (e.g., Ladd 2002). School competition may also create a more business-like and entrepreneurial environment in (private as well as public) schools as administrators and teachers have to face competition from other providers, which may affect students' entrepreneurial traits (cf. Sobel and King 2008). Finally, school competition might force school administrators to be innovative in the supply of courses, teaching methods, and extra-curricular activities that complement students' qualifications beyond the baseline curriculum, so that students leave school with a more balanced portfolio of cognitive and noncognitive skills. Recent theory suggests that such a 'jack-of-all-trades' combination of skills might be particularly supportive of entrepreneurship (Lazear 2004). We provide indicative evidence in favor of these mechanisms.

The database that allows us to assess the impact of school competition on students' entrepreneurial intentions is the 2006 cycle of the Programme for International Student Assessment (PISA), conducted by the Organisation for Economic Co-operation and Development (OECD 2007). PISA is a representative study of 15 -year-olds enrolled in school whose main objective is to assess the mathematical, scientific, and reading literacy of the student population. But additionally, students are asked to report the kind of job they intend to have when they are about 30 years old. From this, we derive an indicator which codes whether they wish to own or to manage a small business, a well-accepted proxy for entrepreneurship (cf. Parker 2010). While this is an indicator of students' entrepreneurial intentions rather actual occupational choices, evidence from the longitudinal British Cohort Study (BCS) shows that the 
entrepreneurial intentions reported at age 16 are a good predictor for actual future entrepreneurial occupations (Falck, Heblich, and Luedemann 2010). ${ }^{2}$

Our research relates to two strands of recent literature in particular. The first strand explores whether entrepreneurial outcomes can be affected by the education system. Most closely related to our paper, Sobel and King (2008) show that, in a cross-section of U.S. counties, counties that have a voucher program also have higher youth entrepreneurship rates. While revealing an important relationship, it is not clear to what extent this association depicts the causal effect of school choice. In a paper focused on the identification of exogenous variation, Oosterbeek, van Praag, and IJsselstein (2010) find no effects of an entrepreneurship education program on entrepreneurial intentions of vocational college students in the Netherlands. Von Graevenitz, Harhoff, and Weber (2010) find similar evidence for Germany (see also their additional references for related studies). Using cross-country data, Falck, Heblich, and Luedemann (2010) find evidence that students' entrepreneurial intentions are related to the entrepreneurial background of their peers' parents. These factors complement other determinants of entrepreneurship stemming from socialization outside the formal education system, such as the role of parents' occupation, gender role models, and ethnicity (see Parker 2009 for a review) and innate biological characteristics (e.g., Nicolaou et al. 2008).

A second strand of related literature analyzes the effects of school choice and competition more generally. ${ }^{3}$ In the last decades, a large of body of literature in the fields of economics, sociology, and political science has discussed the potential costs and benefits arising from school competition (e.g., Coleman, Hoffer, and Kilgore 1982; Hoxby 2003; Chakrabarti and Peterson 2009), nearly exclusively concentrating on cognitive skills, measured by student achievement scores, as outcomes. Several studies that try to estimate effects of private schools in the United States have made use of variation stemming from contemporary variation in Catholic shares (e.g., Hoxby 1994; Evans and Schwab 1995; Sander 1996; Neal 1997; Dee 1998; Jepsen 2002; Altonji, Elder, and Taber 2005; among others), and one from historical Catholic shares (CohenZada 2009). In a setup similar to our study, West and Woessmann (2010) estimate the effect of

2 Similarly, reviewing the psychological and management literature on entrepreneurship as intentional behavior, von Graevenitz, Harhoff, and Weber (2010) conclude that intentions can explain a substantial part of actual variation in entrepreneurial behavior.

${ }^{3}$ Because the general literature on educational production has found little evidence of resource effects (e.g., Woessmann and West 2006), attention has increasingly shifted to effects of institutions of the school system such as choice and competition, accountability, and incentive systems. 
private-school competition on students' academic achievement in mathematics, reading, and science using PISA-2003 data. Despite the increasing awareness of the role of non-cognitive, in addition to cognitive, skills in general (cf. Bowles, Gintis, and Osborne 2001; Heckman, Stixrud, and Urzua 2006), only few studies have looked at effects of school competition beyond academic skills so far. Peterson and Viarengo (2009) show that attending the Catholic private school sector is positively related to a number of non-cognitive outcomes such as engagement, attentiveness, tardiness, and absenteeism in the United States. Looking at school choice in the form of open enrollment in public schools in Chicago, Cullen, Jacob, and Levitt (2006) find little evidence for improvements on traditional academic measures, but positive evidence for improvements on selfreported disciplinary incidents and arrest rates. We are not aware of any evidence on the causal effect of school competition on entrepreneurial traits of students so far.

The remainder of the paper is structured as follows. Section 2 introduces the PISA dataset as source for measuring students' entrepreneurial intentions. Section 3 sets out our estimation strategy. Section 4 reports our results on the effect of private school competition on students' entrepreneurial intentions, along with some indicative analyses of possible underlying mechanisms and several robustness tests. Section 5 concludes.

\section{International Micro Data on Students' Entrepreneurial Intentions}

\subsection{Students' Entrepreneurial Intentions in the PISA-2006 Student Achievement Database}

We use student-level data from the 2006 cycle of the Programme for International Student Assessment (PISA), which was conducted by the Organisation for Economic Co-operation and Development (OECD 2007). The main objective of PISA is to assess the mathematical, scientific, and reading literacy of the student population in each participating country. In addition to the performance tests, students provide detailed information on their personal characteristics and family backgrounds. Moreover, school principals report details on their schools' resource endowments and institutional settings. In each participating country, PISA draws a representative sample of the 15-year-olds enrolled in school. Thus, in most of the countries assessed, the target population comprises young people near the end of their compulsory schooling.

Our dataset contains 192,118 students from 27 countries (see Table 1 for a list of countries). The country sample comprises all OECD member countries, with three exceptions: France, which did not provide school-level background information; Australia, which did not provide 
information on the private operation of schools; and Switzerland, which did not provide entrepreneurial answers in the intended-occupation data. ${ }^{4}$

$<<$ Table 1 about here $>>$

Apart from testing academic achievement, most importantly for our analyses the PISA-2006 survey also questioned students about their occupational intentions, from which we derive a measure of students' entrepreneurial intentions. We draw on students' responses to the question of what kind of job they intend to have when they are about 30 years old. Students were asked to write down the job title. The responses were then coded according to the four-digit International Standard Classification of Occupations (ISCO-88) code by the PISA consortium. The students also provided information on their mother's and father's occupation, which was again given a four-digit ISCO-88 code.

In the ISCO-88 classification, codes starting with 13xx reflect occupations that are related to running small enterprises. The entrepreneurship literature regards these occupational indicators as a good proxy for entrepreneurship (cf. Parker 2010). Consequently, for both the students' intended occupations and the parents' actual occupations, we construct an indicator variable that equals unity if the occupation is entrepreneurial and 0 otherwise. ${ }^{5}$

Table 1 reports descriptive statistics of the students' entrepreneurial intentions and parents’ entrepreneurial occupations at the country level. The share of students with entrepreneurial intentions varies substantially across countries, from less than 1 percent in Denmark, Japan, Germany, and Portugal to more than 7 percent in the Czech Republic and the Netherlands. The international mean is 2.8 percent.

\subsection{Additional International Data}

Our main explanatory variable is the share of students attending privately operated schools in a country. The PISA survey defines private schools as those managed directly or indirectly by

${ }^{4}$ Due to missing data, Austria drops from specifications that include school funding variables.

${ }^{5}$ Most of the students' responses were coded in the general category "Small enterprise: general managers" (ISCO-88 code 1300). Additional narrower categories, available only for a subset of students, indicate businessmen and self-employed managers of small enterprises in different industries, such as manufacturing, merchants, communications, business services, and farming. To ensure that our results are not driven by individual sectors, we performed robustness tests where we dropped each narrower category from the analysis one at a time. Results are fully robust in these regressions. 
a non-government organization. School principals provide information on the private-operation status of their school, which we aggregate to the country level. PISA also provides information on the share of each school's funding stemming from government sources, from which we derive a measure of the average share of government funding in private schools in a country. Table 1 reports descriptive statistics of these and other main explanatory variables for each country. The share of students attending privately operated schools ranges from less than 4 percent in Finland, Iceland, Italy, Norway, Poland, and Turkey to more than 60 percent in Belgium, Ireland, and the Netherlands, with an international mean of 17.9 percent.

The PISA-2006 database provides a rich set of control variables at the student level based on extensive background information drawn from the PISA student and school questionnaires. Table A1 in the appendix lists the full set of control variables of our models with descriptive statistics. They include measures of students' academic achievement, individual and family background variables, indicators of school location, the socio-economic composition of the school, students' learning time, and a set of country-level control variables. ${ }^{6}$

Students' academic achievement is measured by their scores on the PISA tests in mathematics and science. The individual and family background variables include the students’ gender, two indicators for students’ immigrant status (first and second generation immigrant, with native being the residual category), an index of family wealth constructed by PISA, parents' educational attainment, and an indicator of whether parents' occupation is entrepreneurial.

At the school level, control variables include four indicators of the size of the community where the school is located. Furthermore, we constructed five indicators of the socio-economic composition of the school. These encompass the share of peers with entrepreneurial parents, the share of immigrant students, school-average parental education, the school average of an index of home possessions, and the school average of the index of family wealth. In addition, we have four measures of the learning time in regular lessons provided to the student in four subjects.

\footnotetext{
${ }^{6}$ Like any survey dataset, the PISA dataset contains missing values at the student and school level. Although the percentage of missing values is minor for almost any single control variable in our model, deletion of all student observations with a missing value on at least one variable would mean a severe reduction in sample size. We thus perform a simple data imputation of our questionnaire explanatory variables where we replace missing values of continuous variables by the weighted mean at the lowest (school or country) available level and missing values of categorical variables by zero. To ensure that our results are not biased by the inclusion of imputed observations, we then include missing dummies as well as interaction terms of these dummies with the missing variables in all regressions. Observations with missing data on the dependent variable are dropped from the analyses.
} 
We supplement this rich student- and school-level database from PISA-2006 with additional country-level data from several sources. Data on the share of population that was Catholic in 1900 and 2000 and indicators of countries with state religions in 1900, required for our instrumental-variable model, were obtained from the World Christian Encyclopedia (Barrett, Kurian, and Johnson 2001). Barro and McCleary (2005) provide indicators of countries with Communist regimes in 1970. Additional country-level indicators on contemporary gross domestic product (GDP) per capita, cumulative educational expenditure per student between age 6 and 15 in 2002, and curriculum-based external exit exams come from several international statistical sources (cf. Woessmann, Luedemann, Schuetz, and West 2009 for details).

Apart from the set of 27 control variables in our main specification detailed here, we also tested a large set of additional control variables at the student and school level. These additional control variables turned out not to be statistically significantly related to students’ entrepreneurial intentions, individually and jointly, and were consequently dropped from the analysis. These additional variables include such measures as language spoken at home, grade indicators, student's grade repetition, school size, gender share at school, and a rich set of measures of schools' institutional characteristics and resource endowment. The latter include measures of schools' admission practices, selectivity, ability grouping, availability of career guidance, influence and activities of businesses and industry representatives in the school, accountability and autonomy of different forms, and a set of measures of school resources such as average student-teacher ratio, an index of teacher shortage, number of computers for instruction per student, and a school-level index of the quality of school educational resources.

\section{The Empirical Model}

\subsection{School Competition and Students' Entrepreneurial Intentions}

To identify the effect of private school competition on a student's entrepreneurial intention, we estimate the following equation:

$$
\operatorname{Pr}\left(O C C_{i s c} \mid \cdot\right)=\beta_{0}+\beta_{1} P_{c}+X_{c} \beta_{2}+X_{s c} \beta_{3}+X_{i s c} \beta_{4}+\varepsilon_{\text {isc }}
$$

where $\operatorname{Pr}\left(O C C_{i s c} \mid \cdot\right)$ is the conditional probability of student $i$ in school $s$ in country $c$ intending to become an entrepreneur. The country-level variable $P_{c}$ is the share of students attending privately operated schools in country $c$, our measure of the extent of competition from private 
schools within each national school system. The three vectors of control variables at the country $\left(X_{c}\right)$, school $\left(X_{s c}\right)$, and student $\left(X_{i s c}\right)$ level contain the 27 control variables discussed above and listed in Table A1 in the appendix. They include measures of the student's academic achievement, individual and family background, school location, school's socio-economic composition and regular learning time, and the country's GDP per capita and educational spending per student, among others.

Given that the main explanatory variable of interest, the private-school share, is measured at the country level, the mean-zero error term $\varepsilon_{i s c}$ is adjusted to allow for clustering of observations at the country level in all our regressions (cf. Moulton 1986). While the dependent variable is a dummy at the individual level, it is distributed quite evenly at the country level, which provides the variation for our identification. Therefore, all models reported in this paper are estimated as linear probability models, which are straightforward to interpret. However, probit models yield the same results in terms of statistical and quantitative significance. ${ }^{7}$ All regressions weight students by the inverse of their sampling probabilities within countries (DuMouchel and Duncan 1983; Wooldridge 2001), with each country given equal aggregate weight.

Equation (1) depicts a cross-country model that is estimated at the individual student level. The student-level estimation allows us to control for the rich background information at the student and school level. In contrast to within-country studies that are usually bound to analyze limited variation in private-sector competition, however, the cross-country identification allows us to exploit much wider and long-established variation between countries with hardly any nongovernment school and countries with two thirds of their schools being privately operated. This setup is able to capture general-equilibrium effects of private-sector competition.

The major concern for identification in the context of this cross-country setup is that omitted variables of unobserved country features might be correlated with both the extent of private schooling and students' entrepreneurial intentions, introducing bias into ordinary-least-squares (OLS) estimates of $\beta_{1}$. By measuring private schooling as shares at the country level, any sorting of individual students between private and public schools within a country cancels out in our analyses, ruling out bias from within-country sorting. But, most obviously, countries that are more entrepreneurial in general may not only endow their children with higher entrepreneurial

\footnotetext{
${ }^{7}$ Detailed results are available from the authors on request.
} 
intentions, but also be more likely to create private schools. On the other hand, the public school systems in more entrepreneurial countries may already be doing a better job at creating entrepreneurial skills, creating less pressure to set up private alternatives. More generally, omitted variables that could bias the cross-country analysis include any socio-economic, political, or institutional factors that are correlated with students' entrepreneurial intentions and at the same time affect the demand or supply for private schooling. Consequently, the direction of bias created by endogeneity due to unobserved country heterogeneity is a priori unclear.

\subsection{The Instrumental-Variable Model}

To address such concerns of endogeneity bias and identify the causal effect of private school competition on students' entrepreneurial intentions, we identify cross-country variation in the extent of private school competition that results from historical roots in churches' stances regarding state schooling. As suggested by West and Woessmann (2010), the fact that Catholic doctrine in the $19^{\text {th }}$ century strongly resisted state schooling creates a historical "natural" experiment that gives rise to differently sized private-school sectors today. In the late $19^{\text {th }}$ century, the Catholic Church objected to the approach to moral instruction embraced by the state-provided mass education systems that emerged in most industrializing countries. As late as 1912, the Catholic Encyclopedia, summarizing official Catholic doctrine, stated that the "State monopoly of education has been considered by the Church to be nothing short of a tyrannical usurpation” (Herbermann 1912, p. 558).

This Catholic doctrine spurred efforts by local parishes to establish private schools and to lobby governments to adopt policies supporting private schools in many countries (see West and Woessmann 2010 for additional references to official Catholic doctrine and for several historical examples of substantial private-school sectors emerging as a consequence in countries such as Belgium, Ireland, the Netherlands, and the United States). Such efforts were most successful in countries with substantial Catholic shares in the population. As we will show below, Catholic population shares in 1900 are significantly associated with shares of privately operated schools even in 2006, even after controlling for contemporary differences in Catholic shares. An important exception to this rule are countries where Catholicism was the official state religion, because there was no need to create private schools in order to comply with Catholic doctrine in these countries. 
We implement an instrumental-variable model that exploits these historical patterns to isolate current variation in private schooling that we argue is otherwise unrelated to current entrepreneurial intentions. Thus, we use the share of Catholics in 1900 in a country, interacted with an indicator that Catholicism was not official state religion in the country, as an instrument for the country's contemporary share of students attending private schools $P_{c}$ :

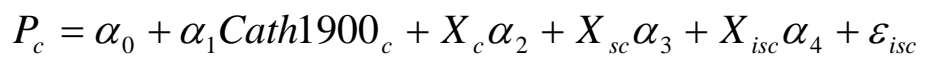

where Cath1900 measures the share of the population of countries without Catholic state religion that was Catholic in 1900. Only that part of the variation in current private-school shares that can be attributed to the historical instrument in this first-stage equation is then used to identify the effect of private-school shares on students' entrepreneurial intentions in the second-stage equation (1).

The identifying assumption of this instrumental-variable approach is that the density of Catholics in 1900 is not directly related to students' entrepreneurial intentions today, independent of the indirect effect running through school competition. The most immediate concern of this identification is that religion may itself be associated with entrepreneurial traits (cf. Dana 2010 for an overview). One of the advantages of our use of historical variation in Catholic shares is that we can address such concerns by controlling for any effect that contemporary differences in Catholic shares might have on students' entrepreneurial intentions.

But even without this fix, there is clear indication in the literature that if anything, any direct effect of Catholicism on entrepreneurship is likely to bias our analyses against finding beneficial effects of school competition. Historical studies have shown a negative association of Catholicism with entrepreneurship in several different historical settings (cf. Weber 1904; Landes 1949; Minns and Rizov 2005). There is also abundant contemporary evidence underscoring that Catholics tend to be less inclined to become entrepreneurs than Protestants (cf. Butler and Herring 1991; Crabtree 2008; and Dana 2009 for a review). In fact, in our analyses below, we will also find a significant negative association between students' entrepreneurial intentions and contemporary Catholicism.

More generally, when it comes to the education system, it has been well documented that Catholics have traditionally placed less emphasis than Protestants on the value of education in general, in particular because Protestants furthered education as a means to facilitate individual 
Bible reading (Rupp 1996; Becker and Woessmann 2009). In 1900, the Catholic population share was strongly negatively correlated with literacy rates $(r=-0.75$; West and Woessmann 2010). Similarly, there is a strong negative association of Catholic shares with GDP per capita in 1900 ( $r=-0.54)$. Taken together, this evidence suggests that by using Catholic-induced variation in private school competition, if anything our results will be biased against finding positive effects on entrepreneurial outcomes.

Another channel through which our instrument might be correlated with the outcome of interest, students' entrepreneurial intentions, is that it may relate to the extent to which students' parents are entrepreneurs. The instrument's relevance suggests that the composition of schools in a country is highly persistent over time. This implies that school competition might already have had an impact on parents' entrepreneurial intentions. Since a child's parents are likely to exert a seminal influence on the child's intentions, it seems quite likely that if the parents are entrepreneurial, their child will be so, as well (cf. Bandura 1977). The entrepreneurship literature provides abundant evidence for the relevance of the intergenerational transmission mechanism within families (cf. Aldrich, Renzulli, and Langton 1998; Dunn and Holtz-Eakin 2000; Hout and Rosen 2000; Fairlie and Robb 2007).

Thus, in order to disentangle the effect of school competition on students' intentions from possible within-family ties, our analyses control for the occupational status of entrepreneurship of individual students' parents. To further rule out that results are driven not by own parents', but by peers' parents' entrepreneurial occupations (cf. Falck, Heblich, and Luedemann 2010), we also control for the occupational status of the parents of students' peers. To the extent that private school competition has already furthered parents' entrepreneurial intentions in the past, controlling for parents' entrepreneurship may actually provide a lower-bound estimate of the total long-run effect of school competition on entrepreneurial outcomes.

Apart from a greater reliance on private schooling, the historical prevalence of Catholicism could in principle also have had other consequences, no longer correlated with current Catholicism, that affect students' entrepreneurial intentions today. It seems that the most likely channels are current GDP per capita or educational spending per student. Consequently, our models control for these variables. West and Woessmann (2010) show that other current outcomes that might be conceived to be related to historical Catholicism, such as the 
decentralization of school policy decision-making, public social spending, and income inequality, are in fact uncorrelated with historical Catholic shares.

A final possible indirect pathway of effects on entrepreneurial intentions is students' academic achievement. To ensure that our results capture effects beyond cognitive skills and not just effects on traditional academic outcomes, our models control for students' PISA test scores in mathematics and science at the individual level.

\section{Results}

\subsection{The Association between Private Schooling and Students' Entrepreneurial Intentions}

As a point of departure, Table 2 reports results from least-squares estimations of equation (1). The share of students in a country who attend privately operated schools is strongly and statistically significantly positively associated with students' entrepreneurial intentions, even after controlling for the large set of student, family, school, and country background factors (cf. Table A1 in the appendix). In line with the previous literature on the intergenerational transmission of entrepreneurship, parents' entrepreneurial status is also significantly positively associated with their children's intention to become an entrepreneur.

\section{$<<$ Table 2 about here $>>$}

The estimates in column (2) are hardly affected by including the Catholic share in 2000 as a control variable, which enters the model negatively (statistically insignificantly in this specification, but significantly in specifications discussed below). The average share of funding that private schools receive from government sources, when added to the model as an additional country-level control variable in column (3), is also statistically insignificant and does not affect the coefficient on the private-school share.

When the sample is restricted in columns (4)-(6) to countries whose population is predominantly Christian, the coefficient on the private-school share increases. All countries in this sample have a share of Christians (from different denominations) in 1900 of more than 85 percent. These specifications do not include Japan (1 percent Christian share), Korea (1 percent), and Turkey (22 percent), where historical Catholic shares are unlikely to be relevant for contemporary private school enrollment. 


\subsection{Instrumental-Variable Results}

In order to obtain a causal estimate of the effect of private school competition on students' entrepreneurial intentions, we turn to the instrumental-variable model derived in Section 3.2. This instrumental-variable approach uses only that part of the contemporary international variation in the share of enrollment in privately operated schools that can be attributed to historical differences in Catholic population shares of countries where Catholicism was not the official state religion. The instrumental-variable results are reported in Table 3.

$<<$ Table 3 about here $>>$

The lower panel of the table reports results of the first-stage equation. The estimates confirm the relevance of the instrument: The Catholic population share in 1900 in countries where Catholicism was not the state religion is significantly associated with the share of students enrolled in privately operated schools in 2006. For each 10 percentage points of additional Catholic share in the 1900 population, the private-school share in 2006 is 4.9 percentage points higher. The high F-statistic of the instrument in the first stage (of 75.6) confirms the strength of the instrument. The covariates show a significant positive association between parents' entrepreneurial status and the private-school share.

Column (2) reveals that the positive association between historical Catholic shares and current private-school shares is still strong when we control for the share of Catholics in the current population. While the current Catholic share enters significantly in predicting privateschool shares, the effect of the historical Catholic share remains strong and significant. Column (3) shows that the private-school share is higher in countries where privately operated schools receive a larger average share of their funding from government sources. Still, controlling for this effect does not affect the association between historical Catholic shares and current privateschool shares.

The second-stage results are reported in the upper panel of Table 3. The results show a statistically and quantitatively significant positive effect of the private-school share on students' intentions to become entrepreneurs. In the instrumental-variable model, this effect is solely identified from variation that can be related back to differences in Catholic population shares in 1900. The point estimate increases significantly when the share of Catholics in the current population is controlled for in column (2), suggesting that the column (1) specification is 
negatively biased because historical Catholic shares capture a negative direct association between Catholic adherence and entrepreneurial intentions. The full results of all control variables in the column (3) model are reported in Table A1 in the appendix.

Our estimates suggest that a 10 percentage-point increase in the share of national enrollment in private schools attributable to a historically larger share of Catholics increases the likelihood of a student having entrepreneurial intentions by 0.3 percentage points in the specification of column (1), and by 0.6 percentage points once the current Catholic share is controlled for. Given that the average share of students with entrepreneurial intentions is 2.8 percent across all OECD countries (cf. Table 1), the effect attributable to private competition in the school system is quite sizable.

The instrumental-variable estimates of Table 3 are higher than the OLS estimates of Table 2. The difference is statistically significant for the specifications reported in columns (2) and (3). This suggests an overall downward bias in the OLS estimates of the effects of private-sector competition in the school system on students' entrepreneurial intentions.

In terms of control variables, the full model reported in Table A1 in the appendix shows that not only the entrepreneurial status of a student's parents, but also the entrepreneurial status of his or her peers' parents are significantly positively associated with the student's own entrepreneurial intentions. The science test score of a student is significantly negatively associated with the student's entrepreneurial intentions. Educational spending per student in the school system is weakly negatively associated with students' entrepreneurial intentions, and the country’s GDP per capita positively.

\subsection{Private Operation or School Competition? Some Evidence on Possible Mechanisms}

The presented estimates of the effect of private-school shares on students' entrepreneurial intentions are reduced-form estimates. They raise the question about the underlying mechanisms and channels through which the effect comes about. Is it that privately operated schools are just better in teaching entrepreneurship? Or is it the competition that larger private-school shares create among schools which is responsible for the positive effect? It is hard to devise identification strategies that are able to convincingly discriminate between the different mechanisms, and we cannot provide conclusive answers in our framework. However, in this section, we report two kinds of indicative analyses that shed some light on these questions. 
In the first analysis, reported in columns (1) and (3) of Table 4, we measure private schooling not as the average at the country level, but directly at the level of individual schools. Lacking an instrument for private schooling at the school level, such a specification does not necessarily identify the causal effect of private school operation because of possible non-random sorting of students between types of schools. Still, the difference in results to the same model when measuring private schooling at the country level (columns (3) and (6) of Table 2) is striking. The size of the coefficient is only about a quarter when measured at the school rather than the country level. Note that standard expectations of bias in the school-level estimate would suggest that it is upwardly biased, because private schools might be able to "cream skim" among the student population. In addition, when entering the school-level and the country-level privateschool measures jointly in columns (2) and (4), the school-level measure does not add significantly positively to the model, and the whole effect is captured by the country-level share of private schools. This pattern of results is indicative of the interpretation that most of the effect of private-school shares does not originate in private schools themselves being inherently more effective in fostering entrepreneurial intentions.

\section{$<<$ Table 4 about here $>>$}

This conclusion is corroborated by the second additional analysis. In columns (5) and (6) of Table 4, we exclude all students attending privately operated schools from the sample, so that in each country, only the students attending public schools are considered. Again, non-random selection between public and private schools in a country would bias the estimate in such a model, and the usual expectation would be a downward bias. But the estimates suggest that students in public schools benefit as much from larger shares of privately operated schools as suggested by the average effects reported in Table 3.

These results are in line with an interpretation that attributes the majority of the estimated effect of private-school shares to changes in the competitive climate in a school system, rather than any advantage of private schools in the effectiveness of their operation. It seems that the prime importance of a larger public-school sector for students' entrepreneurial intentions is that all schools, public as well as private, are exposed to higher intensities of competition.

Finally, it is worth noting that among the indicators of learning time provided to students in different subjects, contained in our set of control variables, only the residual "other" category is 
significantly positively associated with entrepreneurial intentions, whereas learning time in the traditional subjects - mathematics, science, and reading - enters negatively (see Table A1 in the appendix). This pattern of results is consistent with Lazear's (2004) 'jack-of-all-trades' view of entrepreneurs which argues that a more varied curriculum and a more general skill portfolio are supportive of entrepreneurship.

\subsection{Robustness Analyses}

To ensure that our results are not driven by non-Christian countries, columns (4)-(6) of Table 3 perform the analyses on the sub-sample of countries whose population is primarily Christian. The previous estimates based on the full OECD sample are qualitatively unaffected when countries with low shares of Christians (Japan, Korea, and Turkey) are dropped from the sample.

Table 5 shows that the basic result is robust in several sub-samples of countries and to including regional fixed effects. The first column excludes countries that had Catholicism as a state religion. Results are confirmed, although the point estimate declines somewhat. Column (2) disregards countries whose GDP per capita is below 9,000 USD (Mexico and Turkey), indicating that their level of economic development differs markedly from the other OECD countries. Again, results are confirmed.

$<<$ Table 5 about here $>>$

In column (3), we add controls for four world regions - Europe, North America, East Asia, and Oceania - to ensure that results do not just capture variation across regions that may have differing cultures and geographies. Results are hardly affected by adding these region fixed effects. Finally, column (4) restricts the analysis to European countries only, again confirming the main result.

In addition, to ensure that our results are not driven by individual countries, we performed the regressions dropping each individual country from the analysis one at a time. Results are fully robust in these regressions.

The fact that our models include the entrepreneurial status of the occupation of the parents of both the students and their peers among the control variables already indicates that our results capture effects of the current school system on the students, rather than only long-established 
differences in entrepreneurship across countries. In additional robustness specifications, we also added country-level measures of self-employment and entrepreneurship as additional control variables, which did not affect our results. ${ }^{8}$

\section{Conclusions}

Given the important role attributed to entrepreneurs in the long-run growth of economies in a dynamic world, policymakers wonder whether entrepreneurial traits are amenable to fostering in the education system. Our results suggest that this is indeed the case: We find a statistically and quantitatively significant effect of the extent of competition from privately operated schools on the intentions of students towards the end of compulsory school to become entrepreneurs.

Our identification rests on cross-country variation in the size of the private-school sector that can be attributed to international differences in the share of Catholics in the population at the end of the $19^{\text {th }}$ century. Because Catholic doctrine was strongly opposed to the secular state school systems emerging at the time, countries with larger Catholic populations (but without a Catholic state religion) created sizable non-governmental school systems that persist to these days. By drawing on this historical source of variation, we avoid endogeneity biases that may otherwise plague school-choice research. The fact, documented in the literature and apparent in our data, that Catholics in general show lower entrepreneurial aspirations attenuates concerns that our identification draws on variation related to features that are otherwise conducive to entrepreneurship. Furthermore, the use of long-standing and large-scale differences in school competition, drawing on variation between countries from zero to two-thirds privately operated schools, allows us to capture the type of general-equilibrium effects that standard economic thinking has in mind when discussing effects of competition.

Our instrumental-variable results suggest that an increase in a country's share of students attending private schools by 10 percentage points raises a student's likelihood of having entrepreneurial intentions by at least 0.3 percentage points, or 11 percent of the international

\footnotetext{
${ }^{8}$ Self-employment rates are available from the OECD Factbook. Prevalence rates of entrepreneurial activity as well as a categorization of entrepreneurial activity between opportunity and necessity entrepreneurship are available from the Global Entrepreneurship Monitor (GEM). Self-employment rates and opportunity entrepreneurship are negatively and prevalence of entrepreneurial activity is positively associated with students' entrepreneurial intentions. However, including these country-level control variables does not affect our results on the impact of private school competition. Detailed results are available from the authors on request.
} 
mean of students with entrepreneurial intentions. This result is robust to including the parents' occupational status, peers' parents' occupational status, students' academic test scores, the Catholic share in 2000, government funding in private schools, and a large set of additional control variables at the student, school, and country level. The result is also confirmed across various country sub-samples, providing confidence in a causal interpretation of our results. We also provide indicative evidence suggesting that the effect is mostly due to general-equilibrium effects of school competition, rather than due to more effective operation of private schools.

Our results suggest that school competition might not only have an impact on students' cognitive skills measured by test scores, but might also exert important effects beyond traditional cognitive skills. Students' intentions to become an entrepreneur are amenable to institutional features of the school system. Competition from private schools seems to create a climate in the overall school system that is supportive of entrepreneurial intentions. Given that the existing literature suggests that explicit programs of entrepreneurship education may not be able to raise entrepreneurial intentions significantly, this result has important implications for the future direction of discussions about how education systems can promote entrepreneurship. 


\section{References}

Aghion, P. und P. Howitt (2009). The Economics of Growth. Cambridge, MA: MIT Press.

Aldrich, H., Renzulli, L.A. and Langton, N. (1998). Passing on Privilege: Resources Provided by Self-Employed Parents to Their Self-Employed Children. Research in Social Stratification and Mobility, 16, 291-317.

Altonji, J.G., Elder, T.E. and Taber, C.R. (2005). An Evaluation of Instrumental Variable Strategies for Estimating the Effects of Catholic Schooling. Journal of Human Resources, 40, 791-821.

Audretsch, D.B. (2007). The Entrepreneurial Society. Oxford: Oxford University Press.

Bandura, A. (1977). Social Learning Theory. Englewood Cliffs, NJ: Prentice Hall.

Barrett, D.B., Kurian, G.T. and Johnson, T.M. (2001). World Christian Encyclopedia. $2^{\text {nd }}$ edition. Oxford: Oxford University Press.

Barro, R.J. and McCleary, R.M. (2005). Which Countries Have State Religions? Quarterly Journal of Economics, 120, 1331-1370.

Baumol, W.J. (2002). The Free-Market Innovation Machine: Analyzing the Growth Miracle of Capitalism. Princeton, NJ: Princeton University Press.

Becker, S.O. and Woessmann, L. (2009). Was Weber Wrong? A Human Capital Theory of Protestant Economic History. Quarterly Journal of Economics, 124, 531-596.

Bowles, S., Gintis, H. and Osborne, M. (2001). The Determinants of Earnings: A Behavioral Approach. Journal of Economic Literature, 39, 1137-1176.

Butler, J.S. and Herring, C. (1991). Ethnicity and Entrepreneurship in America: Toward an Explanation of Racial and Ethnic Group Variations in Self-Employment. Sociological Perspectives, 34, 79-94.

Chakrabarti, R. and Peterson, P.E., eds. (2009). School Choice International: Exploring PublicPrivate Partnerships. Cambridge, MA: MIT Press.

Cohen-Zada, D. (2009). An Alternative Instrument for Private School Competition. Economics of Education Review, 28, 29-37.

Coleman, J.S., Hoffer, T. and Kilgore, S. (1982). High School Achievement: Public, Catholic, and Private Schools Compared. New York: Basic Books.

Crabtree, S. (2008). Latin America's Entrepreneurs: Catholics vs. Protestants. Gallup Poll. http:// www.gallup.com/poll/108832/latin-americas-entrepreneurs-catholics-vs-protestants.aspx [accessed March 12, 2010].

Cullen, J.B., Jacob, B.A. and Levitt, S. (2006). The Effect of School Choice on Participants: Evidence from Randomized Lotteries. Econometrica, 74, 1191-1230.

Dana, L.P. (2009). Religion as an Explanatory Variable for Entrepreneurship. International Journal of Entrepreneurship and Innovation, 10, 87-99.

Dana, L.P. (2010). Entrepreneurship and Religion. Cheltenham: Edward Elgar.

Dee, T.S. (1998). Competition and the Quality of Public Schools. Economics of Education Review, 17, 419-427. 
DuMouchel, W.H. and Duncan, G.J. (1983). Using Sample Survey Weights in Multiple Regression Analyses of Stratified Samples. Journal of the American Statistical Association, 78, 535-543.

Dunn, T. and Holtz-Eakin, D. (2000). Financial Capital, Human Capital, and the Transition to Self-Employment: Evidence from Intergenerational Links. Journal of Labor Economics, 18, 282-305.

Evans, W.N. and Schwab, R.M. (1995). Finishing High School and Starting College: Do Catholic Schools Make a Difference? Quarterly Journal of Economics, 110, 941-974.

Fairlie, R. and Robb, A. (2007). Why Are Black-Owned Businesses Less Successful than WhiteOwned Businesses? The Role of Families, Inheritances, and Business Human Capital. Journal of Labor Economics, 25, 289-323.

Falck, O., Heblich, S. and Luedemann, E. (2010). Identity and Entrepreneurship: Do School Peers Shape Entrepreneurial Intentions? Small Business Economics, forthcoming.

Friedman, M. (1962). Capitalism and Freedom. Chicago: University of Chicago Press.

Hanushek, E.A. and Woessmann, L. (2008). The Role of Cognitive Skills in Economic Development. Journal of Economic Literature, 46, 607-668.

Heckman, J.J., Stixrud, J. and Urzua, S. (2006). The Effects of Cognitive and Noncognitive Abilities on Labor Market Outcomes and Social Behavior. Journal of Labor Economics, 24, 411-482.

Herbermann, C.G., ed. (1912). The Catholic Encyclopedia: An International Work of Reference on the Constitution, Doctrine, Discipline, and History of the Catholic Church. New York: Robert Appleton Company.

Hout, M. and Rosen, H. (2000). Self-Employment, Family Background, and Race. Journal of Human Resources, 35, 670-692.

Hoxby, C.M. (2003). The Economics of School Choice. Chicago: University of Chicago Press.

Hoxby, C.M. (1994). Do Private Schools Provide Competition for Public Schools? NBER Working Paper 4978. Cambridge, MA: National Bureau of Economic Research.

Jepsen, C. (2002). The Role of Aggregation in Estimating the Effects of Private School Competition on Student Achievement. Journal of Urban Economics, 52, 477-500.

Ladd, H. (2002). School Vouchers: A Critical View. Journal of Economic Perspectives, 16, 3-24.

Landes, D.S. (1949). French Entrepreneurship and Industrial Growth in the Nineteenth Century. Journal of Economic History, 9, 45-61.

Lazear, E. (2004). Balanced Skills and Entrepreneurship. American Economic Review, 94, 208211.

Minns, C. and Rizov, M. (2005). The Spirit of Capitalism? Ethnicity, Religion, and SelfEmployment in Early 20 ${ }^{\text {th }}$ Century Canada. Explorations in Economic History, 42, 259-281.

Moulton, B.R. (1986), Random Group Effects and the Precision of Regression Estimates. Journal of Econometrics, 32, 385-397.

Murphy, K.M., Shleifer, A. and Vishny, R.W. (1991). The Allocation of Talent: Implications for Growth. Quarterly Journal of Economics, 106, 503-530. 
Neal, D. (1997). The Effects of Catholic Secondary Schooling on Secondary Achievement. Journal of Labor Economics, 15, 98-123.

Nicolaou, N., Shane, S., Hunkin, J., Cherkas, L. and Spector, T. (2008). Is the Tendency to Engage in Entrepreneurship Genetic? Management Science, 54, 167-179.

Oosterbeek H., van Praag, M. and IJsselstein, A. (2010). The Impact of Entrepreneurship Education on Entrepreneurship Skills and Motivation. European Economic Review, 54, 442454.

Organisation for Economic Co-operation and Development (OECD) (2007). PISA 2006: Science Competencies for Tomorrow's World. 2 volumes. Paris: OECD.

Parker, S.C. (2009). The Economics of Entrepreneurship. Cambridge: Cambridge University Press.

Parker, S.C. (2010). Small Firms and Innovation. In Audretsch, D.B., Falck, O., Heblich, S. and Lederer, A. (eds.), Handbook of Research on Innovation and Entrepreneurship. Cheltenham: Edward Elgar, in press.

Peterson, P.E. and Viarengo, M.G. (2009). Social Capital and School Sector Impacts on the NonCognitive Skills of Early Adolescents: Evidence from a Nationally Representative Longitudinal Survey. PEPG Working Paper 09-04. Cambridge, MA: Harvard University, Program on Education Policy and Governance.

Rupp, H. (1996). Philipp Melanchthon (1497-1560). Prospects: The Quarterly Review of Comparative Education, 26, 611-21.

Sander, W. (1996). Catholic Grade Schools and Academic Achievement. Journal of Human Resources, 31, 540-548.

Sobel, R.S. and King, K.A. (2008). Does School Choice Increase the Rate of Youth Entrepreneurship? Economics of Education Review, 27, 429-438.

van Praag, C.M. and Versloot, P.H. (2007). What Is the Value of Entrepreneurship? A Review of Recent Research. Small Business Economics, 29, 351-382.

von Graevenitz, G., Harhoff, D. and Weber, R. (2010). The Effects of Entrepreneurship Education. Mimeo, University of Munich.

Weber, M. (1904). Die protestantische Ethik und der „Geist“ des Kapitalismus. Archiv für Sozialwissenschaft und Sozialpolitik 20: 1-54, 1904; 21: 1-110, 1905. [The Protestant Ethic and the Spirit of Capitalism, 1930/2001, London: Routledge Classics.]

West, M.R. and Woessmann, L. (2010). 'Every Catholic Child in a Catholic School': Historical Resistance to State Schooling, Contemporary Private Competition, and Student Achievement across Countries. Economic Journal, forthcoming.

Wooldridge, J.M. (2001). Asymptotic Properties of Weighted M-Estimators for Standard Stratified Samples. Econometric Theory, 17, 451-470.

Woessmann, L., Luedemann, E., Schuetz, G. and West, M.R. (2009). School Accountability, Autonomy and Choice around the World. Cheltenham: Edward Elgar.

Woessmann, L. and West, M.R. (2006). Class-Size Effects in School Systems around the World: Evidence from Between-Grade Variation in TIMSS. European Economic Review, 50, 695736. 
Table 1: Country-Level Descriptive Statistics

\begin{tabular}{|c|c|c|c|c|c|c|c|}
\hline & $\begin{array}{c}\text { Share of } \\
\text { students with } \\
\text { entrepreneurial } \\
\text { intentions }\end{array}$ & $\begin{array}{c}\text { Share of } \\
\text { entrepreneurial } \\
\text { parents }\end{array}$ & $\begin{array}{c}\text { Private } \\
\text { school } \\
\text { share }\end{array}$ & $\begin{array}{c}\text { Share of } \\
\text { government } \\
\text { funding in } \\
\text { private schools }\end{array}$ & $\begin{array}{c}\text { Share of } \\
\text { Catholics in } \\
1900\end{array}$ & $\begin{array}{c}\text { Share of } \\
\text { Catholics in } \\
2000\end{array}$ & $\begin{array}{l}\text { Catholic state } \\
\text { religion in } \\
1900\end{array}$ \\
\hline Austria & 0.014 & 0.076 & 0.095 & - & 0.916 & 0.755 & 1 \\
\hline Belgium & 0.032 & 0.093 & 0.688 & 0.851 & 0.974 & 0.809 & 0 \\
\hline Canada & 0.014 & 0.119 & 0.075 & 0.538 & 0.399 & 0.391 & 0 \\
\hline Czech Republic & 0.077 & 0.214 & 0.070 & 0.634 & 0.862 & 0.404 & 0 \\
\hline Denmark & 0.007 & 0.023 & 0.242 & 0.756 & 0.002 & 0.006 & 0 \\
\hline Finland & 0.017 & 0.043 & 0.030 & 0.977 & 0.000 & 0.001 & 0 \\
\hline Germany & 0.009 & 0.041 & 0.058 & 0.782 & 0.357 & 0.335 & 0 \\
\hline Greece & 0.017 & 0.197 & 0.058 & 0.000 & 0.013 & 0.004 & 0 \\
\hline Hungary & 0.014 & 0.045 & 0.168 & 0.779 & 0.606 & 0.609 & 0 \\
\hline Iceland & 0.011 & 0.093 & 0.010 & 0.448 & 0.000 & 0.010 & 0 \\
\hline Ireland & 0.033 & 0.138 & 0.620 & 0.897 & 0.887 & 0.847 & 0 \\
\hline Italy & 0.041 & 0.167 & 0.039 & 0.135 & 0.996 & 0.798 & 1 \\
\hline Japan & 0.007 & 0.071 & 0.316 & 0.327 & 0.001 & 0.004 & 0 \\
\hline Luxembourg & 0.023 & 0.088 & 0.148 & 0.885 & 0.966 & 0.902 & 1 \\
\hline Mexico & 0.012 & 0.044 & 0.165 & 0.008 & 0.908 & 0.900 & 0 \\
\hline Netherlands & 0.074 & 0.128 & 0.676 & 0.956 & 0.351 & 0.345 & 0 \\
\hline New Zealand & 0.050 & 0.177 & 0.059 & 0.149 & 0.135 & 0.128 & 0 \\
\hline Norway & 0.020 & 0.115 & 0.022 & 0.883 & 0.001 & 0.010 & 0 \\
\hline Poland & 0.016 & 0.107 & 0.016 & 0.353 & 0.771 & 0.922 & 0 \\
\hline Portugal & 0.002 & 0.023 & 0.101 & 0.643 & 0.998 & 0.887 & 1 \\
\hline Slovakia & 0.063 & 0.064 & 0.075 & 0.935 & 0.847 & 0.679 & 0 \\
\hline South Korea & 0.036 & 0.292 & 0.464 & 0.552 & 0.005 & 0.069 & 0 \\
\hline Spain & 0.017 & 0.071 & 0.371 & 0.670 & 1.000 & 0.917 & 1 \\
\hline Sweden & 0.045 & 0.166 & 0.083 & 0.989 & 0.000 & 0.019 & 0 \\
\hline Turkey & 0.027 & 0.160 & 0.025 & 0.000 & 0.005 & 0.001 & 0 \\
\hline United Kingdom & 0.027 & 0.131 & 0.079 & 0.129 & 0.064 & 0.093 & 0 \\
\hline United States & 0.028 & 0.094 & 0.080 & 0.020 & 0.142 & 0.182 & 0 \\
\hline
\end{tabular}

Mean of each variable. Sample: OECD countries (except for Australia, France, and Switzerland due to missing data). 
Table 2: The Association between Private School Shares and the Entrepreneurial Intentions of Students

\begin{tabular}{|c|c|c|c|c|c|c|}
\hline & \multicolumn{3}{|c|}{ OECD countries } & \multicolumn{3}{|c|}{ Predominantly Christian countries } \\
\hline & $(1)$ & $(2)$ & (3) & $(4)$ & (5) & (6) \\
\hline Private school share & $\begin{array}{c}0.020^{* * *} \\
(0.003)\end{array}$ & $\begin{array}{c}0.022^{* * *} \\
(0.004)\end{array}$ & $\begin{array}{c}0.022^{* * *} \\
(0.004)\end{array}$ & $\begin{array}{c}0.027^{* * *} \\
(0.004)\end{array}$ & $\begin{array}{c}0.040^{* * *} \\
(0.003)\end{array}$ & $\begin{array}{c}0.042^{* * *} \\
(0.005)\end{array}$ \\
\hline Parents entrepreneurs & $\begin{array}{l}0.044^{* * *} \\
(0.003)\end{array}$ & $\begin{array}{c}0.044^{* * *} \\
(0.003)\end{array}$ & $\begin{array}{l}0.044^{* * *} \\
(0.003)\end{array}$ & $\begin{array}{c}0.049^{* * * *} \\
(0.003)\end{array}$ & $\begin{array}{c}0.049^{* * *} \\
(0.003)\end{array}$ & $\begin{array}{c}0.049^{* * *} \\
(0.003)\end{array}$ \\
\hline Catholic share in 2000 & & $\begin{array}{l}-0.002 \\
(0.003)\end{array}$ & $\begin{array}{l}-0.002 \\
(0.003)\end{array}$ & & $\begin{array}{c}-0.015^{* * *} \\
(0.004)\end{array}$ & $\begin{array}{c}-0.016^{* * *} \\
(0.004)\end{array}$ \\
\hline Government funding in private schools & & & $\begin{array}{c}-0.00004 \\
(0.002)\end{array}$ & & & $\begin{array}{c}-0.001 \\
(0.003)\end{array}$ \\
\hline Observations (students) & 192,118 & 192,118 & 188,075 & 178,112 & 178,112 & 174,069 \\
\hline Clustering units (countries) & 27 & 27 & 26 & 24 & 24 & 23 \\
\hline$R^{2}$ & 0.019 & 0.019 & 0.019 & 0.021 & 0.021 & 0.021 \\
\hline
\end{tabular}

Dependent variable: student's intention to become entrepreneur. Least squares regressions weighted by students' sampling probability. All regressions include control variables for student's academic achievement (2), individual and family background (5), school location (4), socio-economic composition of the school (5), learning time (4), and country-level controls (4) as set out in Table A1, imputation dummies, and interaction terms between imputation dummies and the variables. Country sample: OECD countries (except for Australia, France, and Switzerland due to missing data). "Government funding in private schools" is missing in Austria. "Predominantly Christian countries" refers to countries with a share of adherence to Christian denominations of more than 85 percent in 1900 (which excludes Japan, Korea, and Turkey). Robust standard errors adjusted for clustering at the country level in parentheses. Significance level: ${ }^{* * * *} 1$ percent, ${ }^{* *}$ 5 percent, ${ }^{*} 10$ percent. 
Table 3: Instrumental-Variable Estimates of the Effect of Private School Shares on Students' Entrepreneurial Intentions

\begin{tabular}{|c|c|c|c|c|c|c|}
\hline & \multicolumn{3}{|c|}{ OECD countries } & \multicolumn{3}{|c|}{ Predominantly Christian countries } \\
\hline & $(1)$ & $(2)$ & (3) & $(4)$ & (5) & $(6)$ \\
\hline \multicolumn{7}{|c|}{ Second stage results (Dependent variable: student's intention to become entrepreneur): } \\
\hline Private school share & $\begin{array}{c}0.031^{* * *} \\
(0.004)\end{array}$ & $\begin{array}{c}0.060^{* * *} \\
(0.012)\end{array}$ & $\begin{array}{c}0.066^{* * *} \\
(0.012)\end{array}$ & $\begin{array}{l}0.026^{* * *} \\
(0.005)\end{array}$ & $\begin{array}{l}0.049^{* * *} \\
(0.010)\end{array}$ & $\begin{array}{c}0.055^{* * *} \\
(0.011)\end{array}$ \\
\hline Parents entrepreneurs & $\begin{array}{c}0.044^{* * *} \\
(0.003)\end{array}$ & $\begin{array}{c}0.043^{* * *} \\
(0.003)\end{array}$ & $\begin{array}{c}0.043^{* * *} \\
(0.003)\end{array}$ & $\begin{array}{c}0.049^{* * *} \\
(0.003)\end{array}$ & $\begin{array}{c}0.049^{* * *} \\
(0.003)\end{array}$ & $\begin{array}{c}0.049^{* * *} \\
(0.003)\end{array}$ \\
\hline Catholic share in 2000 & & $\begin{array}{c}-0.021^{* * *} \\
(0.006)\end{array}$ & $\begin{array}{c}-0.020^{* * *} \\
(0.006)\end{array}$ & & $\begin{array}{c}-0.020^{* * *} \\
(0.007)\end{array}$ & $\begin{array}{c}-0.023^{* * *} \\
(0.007)\end{array}$ \\
\hline Government funding in private schools & & & $\begin{array}{c}-0.010^{* * * *} \\
(0.003)\end{array}$ & & & $\begin{array}{l}-0.003 \\
(0.003)\end{array}$ \\
\hline \multicolumn{7}{|c|}{ First stage results (Dependent variable: private school share): } \\
\hline Catholic share in 1900 (no state religion) & $\begin{array}{c}0.494^{* * *} \\
(0.057)\end{array}$ & $\begin{array}{c}0.293^{* * *} \\
(0.054)\end{array}$ & $\begin{array}{l}0.283^{* * *} \\
(0.049)\end{array}$ & $\begin{array}{l}0.549^{* * *} \\
(0.058)\end{array}$ & $\begin{array}{l}0.336^{* * *} \\
(0.055)\end{array}$ & $\begin{array}{c}0.315^{* * *} \\
(0.049)\end{array}$ \\
\hline Parents entrepreneurs & $\begin{array}{c}0.007^{\text {**** }} \\
(0.001)\end{array}$ & $\begin{array}{c}0.010^{* * *} \\
(0.001)\end{array}$ & $\begin{array}{c}0.014^{* * *} \\
(0.001)\end{array}$ & $\begin{array}{c}-0.003^{* * *} \\
(0.001)\end{array}$ & $\begin{array}{l}0.0001 \\
(0.001)\end{array}$ & $\begin{array}{c}0.006^{* * *} \\
(0.001)\end{array}$ \\
\hline Catholic share in 2000 & & $\begin{array}{c}0.291^{* * *} \\
(0.008)\end{array}$ & $\begin{array}{c}0.207^{* * *} \\
(0.008)\end{array}$ & & $\begin{array}{c}0.342^{* * *} \\
(0.008)\end{array}$ & $\begin{array}{c}0.290^{* * * *} \\
(0.008)\end{array}$ \\
\hline Government funding in private schools & & & $\begin{array}{c}0.215^{* * *} \\
(0.005)\end{array}$ & & & $\begin{array}{c}0.167^{* * *} \\
(0.004)\end{array}$ \\
\hline Observations (students) & 192,118 & 192,118 & 188,075 & 178,112 & 178,112 & 174,069 \\
\hline Clustering units (countries) & 27 & 27 & 26 & 24 & 24 & 23 \\
\hline F-statistic of excluded instrument & 75.62 & 29.21 & 32.92 & 89.96 & 37.63 & 41.19 \\
\hline$R^{2}$ (first stage) & 0.465 & 0.527 & 0.593 & 0.569 & 0.655 & 0.700 \\
\hline$R^{2}$ (second stage) & 0.019 & 0.018 & 0.018 & 0.021 & 0.021 & 0.021 \\
\hline
\end{tabular}

Two-stage least squares regressions weighted by students' sampling probability. All regressions include control variables for student's academic achievement (2), individual and family background (5), school location (4), socio-economic composition of the school (5), learning time (4), and country-level controls (4) as set out in Table A1, imputation dummies, and interaction terms between imputation dummies and the variables. Country sample: OECD countries (except for Australia, France, and Switzerland due to missing data). "Government funding in private schools" is missing in Austria. "Predominantly Christian countries" refers to countries with a share of adherence to Christian denominations of more than 85 percent in 1900 (which excludes Japan, Korea, and Turkey). "Catholic share in 1900 (no state religion)" refers to the share of Catholics in the population in 1900 interacted with an indicator of whether Catholicism was the state religion. Robust standard errors adjusted for clustering at the country level in parentheses. Significance level: ${ }^{* * *} 1$ percent, ${ }^{* *} 5$ percent, ${ }^{*} 10$ percent. 
Table 4: School-Level Private Operation, System-Level Competition, and Public-School Students' Outcomes

\begin{tabular}{|c|c|c|c|c|c|c|}
\hline & \multicolumn{4}{|c|}{ Measuring private operation at the school level } & \multicolumn{2}{|c|}{$\begin{array}{l}\text { Restricting sample to students } \\
\text { in public schools only }\end{array}$} \\
\hline & \multicolumn{2}{|c|}{ OECD countries } & \multicolumn{2}{|c|}{$\begin{array}{l}\text { Predominantly } \\
\text { Christian countries }\end{array}$} & \multirow{2}{*}{$\begin{array}{c}\text { OECD } \\
\text { countries } \\
\text { (5) }\end{array}$} & \multirow{2}{*}{$\begin{array}{c}\text { Pred. Christ. } \\
\text { countries } \\
\text { (6) }\end{array}$} \\
\hline & (1) & (2) & (3) & (4) & & \\
\hline Private school (measured at school level) & $\begin{array}{l}0.006^{* * *} \\
(0.002)\end{array}$ & $\begin{array}{l}-0.006^{*} \\
(0.003)\end{array}$ & $\begin{array}{l}0.010^{* * *} \\
(0.003)\end{array}$ & $\begin{array}{c}0.002 \\
(0.003)\end{array}$ & & \\
\hline Private school share & & $\begin{array}{l}0.073^{* * *} \\
(0.014)\end{array}$ & & $\begin{array}{l}0.055^{* * * *} \\
(0.013)\end{array}$ & $\begin{array}{c}0.073^{* * *} \\
(0.022)\end{array}$ & $\begin{array}{l}0.064^{* * *} \\
(0.019)\end{array}$ \\
\hline Parents entrepreneurs & $\begin{array}{l}0.044^{* * *} \\
(0.003)\end{array}$ & $\begin{array}{l}0.043^{* * *} \\
(0.003)\end{array}$ & $\begin{array}{l}0.049^{* * *} \\
(0.003)\end{array}$ & $\begin{array}{l}0.049^{* * *} \\
(0.003)\end{array}$ & $\begin{array}{l}0.042^{* * *} \\
(0.003)\end{array}$ & $\begin{array}{l}0.046^{* * *} \\
(0.004)\end{array}$ \\
\hline Catholic share in 2000 & $\begin{array}{c}0.004 \\
(0.003)\end{array}$ & $\begin{array}{c}-0.020^{* * *} \\
(0.006)\end{array}$ & $\begin{array}{l}-0.0007 \\
(0.004)\end{array}$ & $\begin{array}{c}-0.024^{* * *} \\
(0.007)\end{array}$ & $\begin{array}{c}-0.023^{* * *} \\
(0.009)\end{array}$ & $\begin{array}{c}-0.026^{* * *} \\
(0.010)\end{array}$ \\
\hline Government funding in private schools & $\begin{array}{c}0.003 \\
(0.002)\end{array}$ & $\begin{array}{c}-0.010^{* * *} \\
(0.003)\end{array}$ & $\begin{array}{l}0.005^{*} \\
(0.003)\end{array}$ & $\begin{array}{l}-0.003 \\
(0.003)\end{array}$ & $\begin{array}{l}-0.010^{* *} \\
(0.004)\end{array}$ & $\begin{array}{c}-0.005^{* * *} \\
(0.003)\end{array}$ \\
\hline Observations (students) & 184,583 & 184,583 & 170,605 & 170,605 & 150,715 & 140,660 \\
\hline Clustering units (countries) & 26 & 26 & 23 & 23 & 26 & 23 \\
\hline$R^{2}$ (second stage) & 0.019 & 0.018 & 0.021 & 0.021 & 0.016 & 0.019 \\
\hline$R^{2}$ (first stage) & & 0.651 & & 0.738 & 0.593 & 0.708 \\
\hline F-statistic of excluded instrument & & 25.70 & & 19.18 & 24.05 & 28.30 \\
\hline
\end{tabular}

Dependent variable: student's intention to become entrepreneur. Columns (1) and (3): Least squares regressions weighted by students' sampling probability. Columns (2) and (4)-(6): Two-stage least squares regressions weighted by students' sampling probability, using the share of Catholics in the population in 1900 interacted with an indicator of whether Catholicism was the state religion as an instrument for the private school share. All regressions include control variables for student's academic achievement (2), individual and family background (5), school location (4), socio-economic composition of the school (5), learning time (4), and country-level controls (4) as set out in Table A1, imputation dummies, and interaction terms between imputation dummies and the variables. Country sample: OECD countries (except for Australia, Austria, France, and Switzerland due to missing data). "Predominantly Christian countries" refers to countries with a share of adherence to Christian denominations of more than 85 percent in 1900 (which excludes Japan, Korea, and Turkey). Robust standard errors adjusted for clustering at the country level in parentheses. Significance level: ${ }^{* * *} 1$ percent, ${ }^{* *} 5$ percent, ${ }^{*} 10$ percent. 
Table 5: Robustness to Sub-Samples of Countries and Regional Fixed Effects

\begin{tabular}{|c|c|c|c|c|}
\hline Sample of countries: & $\begin{array}{c}\text { No Catholic } \\
\text { state religion } \\
(1)\end{array}$ & $\begin{array}{l}\text { GDP per capita } \\
>9,000 \text { USD } \\
(2)\end{array}$ & $\begin{array}{l}\text { OECD with } \\
\text { region dummies } \\
(3)\end{array}$ & $\begin{array}{c}\text { Europe only } \\
\text { (4) }\end{array}$ \\
\hline \multicolumn{5}{|c|}{ Second stage results (Dependent variable: student's intention to become entrepreneur): } \\
\hline Private school share & $\begin{array}{c}0.022^{* * *} \\
(0.003)\end{array}$ & $\begin{array}{c}0.046^{* * *} \\
(0.009)\end{array}$ & $\begin{array}{l}0.054^{* * *} \\
(0.010)\end{array}$ & $\begin{array}{l}0.046^{* * *} \\
(0.010)\end{array}$ \\
\hline Parents entrepreneurs & $\begin{array}{c}0.037^{* * *} \\
(0.003)\end{array}$ & $\begin{array}{l}0.045^{* * *} \\
(0.003)\end{array}$ & $\begin{array}{l}0.044^{* * *} \\
(0.003)\end{array}$ & $\begin{array}{l}0.052^{* * *} \\
(0.003)\end{array}$ \\
\hline Catholic share in 2000 & $\begin{array}{c}-0.112^{* * *} \\
(0.015)\end{array}$ & $\begin{array}{c}-0.013^{* *} \\
(0.006)\end{array}$ & $\begin{array}{c}-0.025^{* * *} \\
(0.006)\end{array}$ & $\begin{array}{l}-0.018^{* *} \\
(0.007)\end{array}$ \\
\hline Government funding in private schools & $\begin{array}{c}-0.038^{* * *} \\
(0.006)\end{array}$ & $\begin{array}{l}-0.004 \\
(0.003)\end{array}$ & $\begin{array}{c}0.002 \\
(0.003) \\
\end{array}$ & $\begin{array}{l}0.011^{* * *} \\
(0.003)\end{array}$ \\
\hline \multicolumn{5}{|c|}{ First stage results (Dependent variable: private school share): } \\
\hline Catholic share in 1900 (no state religion) & $\begin{array}{c}0.418^{* * *} \\
(0.073)\end{array}$ & $\begin{array}{l}0.433^{* * *} \\
(0.062)\end{array}$ & $\begin{array}{l}0.356^{* * *} \\
(0.048)\end{array}$ & $\begin{array}{c}0.394^{* * *} \\
(0.056)\end{array}$ \\
\hline Parents entrepreneurs & $\begin{array}{l}0.018^{* * *} \\
(0.001)\end{array}$ & $\begin{array}{l}0.008^{* * *} \\
(0.001)\end{array}$ & $\begin{array}{l}0.006^{* * *} \\
(0.001)\end{array}$ & $\begin{array}{l}0.002^{*} \\
(0.001)\end{array}$ \\
\hline Catholic share in 2000 & $\begin{array}{c}0.151^{* * *} \\
(0.012)\end{array}$ & $\begin{array}{c}0.187^{* * *} \\
(0.009)\end{array}$ & $\begin{array}{c}0.263^{* * *} \\
(0.006)\end{array}$ & $\begin{array}{c}0.315^{* * *} \\
(0.008)\end{array}$ \\
\hline Government funding in private schools & $\begin{array}{c}0.169^{* * *} \\
(0.005)\end{array}$ & $\begin{array}{c}0.162^{* * * *} \\
(0.004)\end{array}$ & $\begin{array}{c}0.128^{* * *} \\
(0.004)\end{array}$ & $\begin{array}{l}0.110^{* * *} \\
(0.005)\end{array}$ \\
\hline Observations (students) & 143,228 & 158,260 & 188,075 & 117,722 \\
\hline Clustering units (countries) & 22 & 24 & 26 & 19 \\
\hline F-statistic of excluded instrument & 33.08 & 49.51 & 55.61 & 49.29 \\
\hline$R^{2}$ (first stage) & 0.640 & 0.657 & 0.751 & 0.8783 \\
\hline$R^{2}$ (second stage) & 0.002 & 0.019 & 0.020 & 0.024 \\
\hline
\end{tabular}

Two-stage least squares regressions weighted by students' sampling probability. All regressions include 24 additional background control variables as set out in Table A1, imputation dummies, and interaction terms between imputation dummies and the variables. Country sample: OECD countries (except for Austria, Australia, France, and Switzerland due to missing data). Column (1) excludes Italy, Luxembourg, Portugal, and Spain. Column (2) excludes Mexico and Turkey. Column (3) includes region dummies for Europe, East Asia, North America, and Oceania. "Catholic share in 1900 (no state religion)" refers to the share of Catholics in the population in 1900 interacted with an indicator of whether Catholicism was the state religion. Robust standard errors adjusted for clustering at the country level in parentheses. Significance level: ${ }^{* * *} 1$ percent, ${ }^{* *} 5$ percent, ${ }^{*} 10$ percent. 


\begin{tabular}{|c|c|c|c|c|c|c|}
\hline & \multicolumn{2}{|c|}{ Descriptive Statistics } & \multicolumn{4}{|c|}{ Main Model } \\
\hline & \multirow{2}{*}{$\begin{array}{l}\text { Mean } \\
\text { (1) }\end{array}$} & \multirow{2}{*}{$\begin{array}{l}\text { Std. dev. } \\
\text { (2) }\end{array}$} & \multicolumn{2}{|c|}{$\begin{array}{c}\text { First stage } \\
\text { (dep. var.: private } \\
\text { school share) }\end{array}$} & \multicolumn{2}{|c|}{$\begin{array}{c}\text { Second stage } \\
\text { (dep. var.: student's } \\
\text { entrepreneurial intention) }\end{array}$} \\
\hline & & & $\begin{array}{l}\text { Coeff. } \\
\text { (3) }\end{array}$ & $\begin{array}{l}\text { Std. Err. } \\
\text { (4) }\end{array}$ & $\begin{array}{l}\text { Coeff. } \\
\text { (5) }\end{array}$ & $\begin{array}{l}\text { Std. Err. } \\
\text { (6) }\end{array}$ \\
\hline Student's intention to become entrepreneur & 0.028 & 0.163 & & & & \\
\hline $\begin{array}{l}\text { Private school share } \\
\text { Catholic share in } 1900 \text { (no state religion) } \\
\text { Parents entrepreneur } \\
\text { Catholic share in } 2000 \\
\text { Government funding share in private schools }\end{array}$ & $\begin{array}{l}0.179 \\
0.271 \\
0.111 \\
0.408 \\
0.550\end{array}$ & $\begin{array}{l}0.202 \\
0.357 \\
0.312 \\
0.366 \\
0.345\end{array}$ & $\begin{array}{l}0.283^{* * *} \\
0.014^{* * *} \\
0.207^{* * *} \\
0.215^{* * *}\end{array}$ & $\begin{array}{l}(0.049) \\
(0.001) \\
(0.008) \\
(0.005)\end{array}$ & $\begin{array}{l}0.066^{* * *} \\
0.043^{* * *} \\
-0.020^{* * *} \\
-0.010^{* * *}\end{array}$ & $\begin{array}{l}(0.003) \\
(0.006) \\
(0.003)\end{array}$ \\
\hline Student's academic achievement & & & & & & \\
\hline $\begin{array}{l}\text { Mathematics test score } \\
\text { Science test score }\end{array}$ & $\begin{array}{l}500.009 \\
504.070\end{array}$ & $\begin{array}{l}94.706 \\
97.235\end{array}$ & $\begin{array}{l}0.0003^{* * *} \\
-0.0001^{* * *}\end{array}$ & $\begin{array}{l}(0.00002) \\
(0.00002)\end{array}$ & -0.00002 & $\begin{array}{l}(0.00001) \\
(0.00001)\end{array}$ \\
\hline $\begin{array}{l}\text { Individual and family background variables } \\
\text { Female } \\
\text { First generation immigrant } \\
\text { Second generation immigrant } \\
\text { PISA index of family wealth } \\
\text { Years of schooling of parents }\end{array}$ & $\begin{array}{c}0.511 \\
0.036 \\
0.040 \\
0.003 \\
13.051\end{array}$ & $\begin{array}{l}0.500 \\
0.188 \\
0.199 \\
1.010 \\
3.266\end{array}$ & $\begin{array}{l}0.006^{* * *} \\
-0.004 \\
-0.007^{* * *} \\
-0.0004^{*} \\
-0.0009^{* * *}\end{array}$ & $\begin{array}{l}(0.002) \\
(0.003) \\
(0.002) \\
0.0002) \\
(0.0001)\end{array}$ & $\begin{array}{l}-0.014^{* * *} \\
0.008^{* *} \\
0.008^{* * *} \\
0.006^{* * *} \\
-0.0003^{*}\end{array}$ & $\begin{array}{l}(0.001) \\
(0.003) \\
(0.003) \\
(0.0007) \\
(0.0002)\end{array}$ \\
\hline $\begin{array}{l}\text { School location } \\
\text { Small town (3,000-15,000 people) } \\
\text { Town (15,000-100,000 people) } \\
\text { City (100,000-1,000 } 000 \text { people) } \\
\text { Large city (over } 1,000,000 \text { people) }\end{array}$ & $\begin{array}{l}0.216 \\
0.342 \\
0.212 \\
0.108 \\
\end{array}$ & $\begin{array}{l}0.414 \\
0.473 \\
0.408 \\
0.313 \\
\end{array}$ & $\begin{array}{l}0.028^{* * * *} \\
0.066^{* * *} \\
0.093^{* * *} \\
0.131^{* * *}\end{array}$ & $\begin{array}{l}(0.006) \\
(0.006) \\
(0.007) \\
(0.008) \\
\end{array}$ & $\begin{array}{c}0.005^{* *} \\
0.009^{* * *} \\
0.003 \\
0.0003 \\
\end{array}$ & $\begin{array}{l}(0.002) \\
(0.002) \\
(0.002) \\
(0.003) \\
\end{array}$ \\
\hline
\end{tabular}

(continued on next page) 


\begin{tabular}{|c|c|c|c|c|c|c|}
\hline & \multicolumn{2}{|c|}{ Descriptive Statistics } & \multicolumn{4}{|c|}{ Main Model } \\
\hline & \multirow[b]{2}{*}{$\begin{array}{c}\text { Mean } \\
(1)\end{array}$} & \multirow[b]{2}{*}{$\begin{array}{l}\text { Std. dev. } \\
\text { (2) }\end{array}$} & \multicolumn{2}{|c|}{ First stage } & \multicolumn{2}{|c|}{ Second stage } \\
\hline & & & $\begin{array}{c}\text { Coeff. } \\
\text { (3) }\end{array}$ & $\begin{array}{c}\text { Std. Err. } \\
\text { (4) }\end{array}$ & $\begin{array}{c}\text { Coeff. } \\
(5)\end{array}$ & $\begin{array}{c}\text { Std. Err. } \\
\text { (6) }\end{array}$ \\
\hline \multicolumn{7}{|l|}{ Socio-economic composition of school } \\
\hline Share of peers with entrepreneurial parents & 0.111 & 0.101 & $0.313^{* * *}$ & $(0.016)$ & $0.065^{* * *}$ & $(0.009)$ \\
\hline Share of immigrant students & 0.076 & 0.147 & $-0.147^{* * *}$ & $(0.015)$ & $0.022^{* * *}$ & $(0.006)$ \\
\hline School average parental education & 12.848 & 2.025 & $0.006^{* * *}$ & $(0.001)$ & $-0.001^{* *}$ & $(0.0006)$ \\
\hline School average index of home possessions & 0.005 & 0.594 & $-0.200^{* * *}$ & $(0.008)$ & $0.011^{* *}$ & $(0.006)$ \\
\hline School average index of family wealth & 0.003 & 0.697 & $0.185^{* * *}$ & $(0.007)$ & $-0.010^{* *}$ & $(0.004)$ \\
\hline \multicolumn{7}{|l|}{ Learning time in regular lessons } \\
\hline Mathematics & 3.843 & 1.704 & 0.00001 & $(0.0006)$ & $-0.001^{* * *}$ & $(0.0004)$ \\
\hline Science & 3.055 & 1.963 & $-0.004^{* * *}$ & $(0.0004)$ & $-0.002^{* * *}$ & $(0.0003)$ \\
\hline Reading & 3.826 & 1.724 & $0.003^{* * *}$ & $(0.0005)$ & -0.0004 & $(0.0004)$ \\
\hline Other & 4.075 & 2.180 & $-0.004^{* * *}$ & $(0.0003)$ & $0.002^{* * *}$ & $(0.0003)$ \\
\hline \multicolumn{7}{|l|}{ Country-level control variables } \\
\hline Contemporary GDP per capita (1,000 \$) & 22.424 & 9.127 & $-0.007^{* * *}$ & $(0.0005)$ & $0.0006^{* * *}$ & $(0.0002)$ \\
\hline Educational expenditure per student $(1,000 \$)$ & 54.700 & 25.672 & $0.001^{* * *}$ & $(0.0002)$ & $-0.0002^{*}$ & $(0.00008)$ \\
\hline External exit exams & 0.693 & 0.448 & $0.063^{* * *}$ & $(0.004)$ & -0.002 & $(0.002)$ \\
\hline Communist background & 0.162 & 0.354 & $-0.368^{* * *}$ & $(0.006)$ & $0.037^{* * *}$ & $(0.005)$ \\
\hline Observations (students) & & & 188,075 & & 188,075 & \\
\hline Clustering units (countries) & & & 26 & & 26 & \\
\hline$R^{2}$ & & & 0.593 & & 0.018 & \\
\hline
\end{tabular}

Descriptive statistics: Mean: international mean (weighted by sampling probabilities). Std. dev.: international standard deviation.

Main model: Full results of the specification reported in column (3) of Table 3. Two-stage least squares regressions weighted by students' sampling probability. Regression includes imputation dummies and interaction terms between imputation dummies and the variables. Country sample: OECD countries (except for Australia, Austria, France, and Switzerland due to missing data). "Catholic share in 1900 (no state religion)" refers to the share of Catholics in the population in 1900 interacted with an indicator of whether Catholicism was the state religion. Robust standard errors adjusted for clustering at the country level in parentheses. Significance level: ${ }^{* * *} 1$ percent, ${ }^{* *} 5$ percent, ${ }^{*} 10$ percent. 